\title{
Research on the Trend of Regional Economic Integration under the Perspective of Belt and Road
}

\author{
Fei Wang \\ Communist Party of China Ali Regional Committee Party School, Xizang 859000, China. \\ wftnc@qq.com
}

\begin{abstract}
Keywords: The new economic, economic Belt and Road, regional economic integration, development trend.
\end{abstract}

\begin{abstract}
At present, the world economic recovery is sluggish and development momentum is insufficient. China's economic development has also entered a new normal state. Under the development trend of the new economy, it is imminent to deepen the reform of the economic system, adjust the economic structure, transform the driving factors, and maintain the steady and stable growth of the economy. In this great historical period, the CPC Central Committee and State Council on global vision and look far ahead from a high plane, international vision, aiming at the problem of regional economic development, put forward the development strategy of The Belt and Road ". In the "The Belt and Road" strategy, how to deepen the reform of the integration of regional economic development, regional economic development caliber, and adjustment of the regional economic development structure, regional economy maintained steady growth speed of security is feasible and needs to pay attention to the problem in the process of economic development Chinese. This paper is based on "The Belt and Road" perspective, combined with the development of the domestic regional economic characteristics, to explore and Research on the development of regional economic integration The Belt and Road "strategy under the trend.
\end{abstract}

\section{Introduction}

There are complicated and profound changes in the world today. [1] The deep impact of the international financial crisis on the economy continues to appear, the world economy is slowly recovering, the development and differentiation, the international investment and trade pattern and the multilateral investment and trade rules are brewing a profound adjustment, and the problems faced by various countries are very serious. However, on the other side of the world, China's economic development is a "scenic side". In order to conform to the world's trend of multi polarization, economic globalization, cultural diversity and social information, we hold an open spirit of regional cooperation and strive to maintain and develop the global free trade system and open world economy, and let the people of the world. A ride in China's economic development.

September and October 2013, the party and the state supreme leader President Xi Jinxing during his visit to the Central Asian and Southeast Asian countries,[2] has proposed to build a Silk Road Economic Belt "in twenty-first Century and" maritime Silk Road "is" a major initiative to The Belt and Road ", get the attention of the International community. To build a "The Belt and Road" to promote economic integration of the free flow of factors orderly, efficient allocation of resources and promote the realization of the market depth, along the national economic policy coordination, regional cooperation in a wider scope and higher level, a deeper level, work together to build an open, inclusive, balanced and inclusive regional economic cooperation framework. [3]To build a "The Belt and Road" conforms to the fundamental interests of the international community, highlighting the human society is the common ideal and pursuit, international cooperation and global governance in the new mode of active exploration, will add new energy to world peace and development. 


\section{Strategic Background for the Development of Regional Economic Integration under The "One Belt and One Road" Perspective}

Similar to the ancient Silk Road, the "One Belt and One Road" development strategy is a strategic approach to economic development put forward at the national level after China's economic development has entered a new normal in the new period. [4]By co-building the Belt and Road, it is possible to achieve an all-round cultural and economic interaction between China and the world, which will help ensure the stable and moderate growth of China's economy under the new normal economy. Since General Secretary Xi Jinping proposed the "One Belt, One Road" strategic strategy for the first time between September and October 2013, the "One Belt and One Road" development strategy has received a warm response from many countries and regions along the route. Table 1 shows some of the domestic and foreign regions involved in the "One Belt and One Road" development strategy.

Table. 1 Belt and Road Initiative relates to coastal countries and regions

\begin{tabular}{ccc}
\hline & China & Other countries \\
\hline $\begin{array}{c}\text { The economic belt of } \\
\text { the Silk Road }\end{array}$ & $\begin{array}{c}\text { Beijing, Chongqing, Henan, Shaanxi, Gansu, Ningxia, } \\
\text { Qinghai, Xinjiang, Inner Mongolia, Heilongiang, Jilin, } \\
\text { Liaoning, Guangxi, Yunnan, Tibet } \\
\begin{array}{c}\text { The Silk Road on the } \\
\text { sea in twenty-first } \\
\text { Century }\end{array}\end{array}$ & $\begin{array}{c}\text { Central Asia, Western Asia, } \\
\text { Russia, parts of Europe }\end{array}$ \\
$\begin{array}{c}\text { Shanghai, Tianjin, Hong Kong, Shandong, Zhejiang, } \\
\text { Fujian, Guangdong, Hainan }\end{array}$ & $\begin{array}{c}\text { East Asia, South Asia, } \\
\text { Africa, Mediterranean } \\
\text { region }\end{array}$ \\
\hline
\end{tabular}

\section{The Belt and Road Construction Can Promote the Rapid Development of Regional Economic Development in China}

There is a serious imbalance of development in China's economy, which is mainly reflected in the southeast coastal areas and the central and western regions. [4]Because of its advantaged resources, talents and policy advantages, the southeast coastal area has been far ahead of the inland, central and western regions. The central and western regions are still the "short board" of China's regional development. It is the difficult and key point of building a well-off society in an all-round way. It is necessary to understand the central and western regions from the overall and strategic level. It is necessary to fully recognize the importance of the reform, opening up and socialist modernization in the western region, the importance of the long-term stability of the country and the great rejuvenation of the Chinese nation, and to promote the prosperity, development and stability of the western region by speeding up the pace of opening up.[5] "This The Belt and Road" strategy, is to give full play to the comparative advantages of different regions in China, the implementation of a more proactive strategy of opening up. The development strategy of "The Belt and Road" can not only provide the conditions for development, but also provides a strategic starting point for along national and regional coordinated development.

"Belt and Road Initiative" strategy based on international and domestic two resources, two markets, the effective convergence of interests between countries along. [6] The first is that this strategy will solve the problem of regional coordinated development under the international background, and co-ordinate the two major international and domestic situations, so that many problems that cannot be solved at home will be solved. For example, China's iron and steel surplus, but many countries along the line are accelerating industrialization, requires a lot of iron and steel and building materials. Second, it can better meet the development needs of Asian European and African countries. China will promote the common development of the countries along the belt by means of ribbon economy, corridor economy, trade facilitation, technical assistance and economic assistance. [7] Since the international financial crisis, the structural contradictions in the above areas are prominent, the internal economic growth is lacking, and the western developed countries cannot be the "engine" to lead the region's economic development. China has a wide market, relatively mature technology, 
abundant capital and stable economy for a long time. Most of the countries along the line hope to develop "express" in China. Furthermore, Belt and Road Initiative "strategy is conducive to the promotion of China's western development. China's steel, cement, building materials and other industries are overcapacity, and can be transferred outwards by trade and foreign investment. And with the implementation of the "The Belt and Road" strategy, to increase the use of RMB and management system reform, is conducive to the formation of a regional financial center in the mid-west.

\section{The Development of Regional Economic Integration in China from the Perspective of 3. Belt and Road Initiative}

\subsection{Regional Economic Growth Slowed Down and Maintained Steady Growth at Medium Speed.}

"Belt and Road Initiative" is put forward Chinese economy under the new normal based strategy, it should be noted that the new economic norm is a kind of "economic structure", which not only focus on the economy, but also pay more attention to the sustainable development of economy. [8]For a long time, the "efficiency economy" has always been an important economic foundation of our country. Admittedly, with the deepening of reform and opening up, the "efficiency economy" has made an important contribution to the development of China's economy, which has made the regional economy showing a rapid development trend (even once a number of developed countries), but the rapid growth of regional economy brought by the "efficiency economy" is for China. However, because of the rapid growth of regional economy, China is facing enormous environmental and resource pressure, and the distribution of social wealth presents a serious polarization trend. At the same time, the rapid economic growth is easy to lead to the bubble economy and produce economic crisis. Therefore, in the "The Belt and Road" strategy, the slower pace of economic growth area, showing a moderate steady growth trend. According to statistics, the growth rate of China's gross national product has been decreasing gradually, the regional economic growth rate has slowed down, and the steady growth has been maintained at medium speed. Since Xi Jinxing General Secretary proposed the "The Belt and Road" strategy, Chinese attaches great importance to the adjustment and optimization of regional economic structure. [9]General Secretary Xi Jinxing pointed out that China's economic growth should strive to upgrade from traditional investment driven, factor driven to innovative driven. It can be seen that in the "The Belt and Road" strategy under the guidance of China will be in the economic transition period of development in a longer period of time, the regional economy have maintained a steady growth trend of medium speed.

\subsection{Broaden Cooperation Channels and Accelerate the Development of Regional Economic Integration.}

In the past period of time, the economic cooperation between China and foreign countries is relatively narrow, which is often concentrated in the traditional fields such as agriculture, handicraft industry, manufacturing industry and so on, and the channels of cooperation are relatively limited. In the "The Belt and Road" strategy, China and foreign economic cooperation has been greatly widen the aperture. "The Belt and Road construction in transportation infrastructure construction as the foundation, through the cultivation of new economic starting point and market competitive advantage and expand economic cooperation channels Belt and Road Initiative along the country, thus speeding up the development of regional economic integration.[10]"The Belt and Road" strategy will be mainly through the construction of infrastructure, economic and trade cooperation, financial cooperation and other ways to achieve between China exchanges and cooperation with other countries.

\section{Summary}

The development strategy of "The Belt and Road" is not only is Chinese regional economic development blueprint, also in the world Chinese further into the economy, driven by the historic initiative the common development of the regional economy, the continuous development in the 
regional economic integration today, the development strategy of "The Belt and Road" will lead to more countries and regions along the We should make joint efforts to achieve economic growth and create a new world pattern of peace, stability and prosperity.

\section{References}

[1]. Roan Feng in. Regional economic internationalization and The Belt and Road [N]. Gang Ming Daily, 2015-03-18.

[2]. Feng Dongxiang. The strategic significance of The Belt and Road conception [N]. Gang Ming Daily, 2014-10-20.

[3]. Summary of opinions and suggestions of experts at home and abroad about The Belt and Road construction. China economic times, 2014-08-21.

[4]. The commentators of this magazine jointly built the "Belt and Road" strategy to create a new pattern of China's all-round opening up to the outside world [J]. Seeking Truth, 2015(05).

[5]. "Visions and Actions for Promoting the Joint Construction of the Silk Road Economic Belt and the 21st Century Maritime Silk Road", People's Daily, March 29, 2015, 4th edition.

[6]. Shan Wuxia. The "Belt and Road" Strategy of China's Regional Economic Cooperation and Its Effect Analysis [D]. Zhejiang University.

[7]. Dang Jeanie. The influence of the development of the Silk Road Economic Belt on the future development of important node cities along the route [J]. Continental Bridge Vision, 2014 (5) : $49-51$.

[8]. Feng Bing. "Belt and Road" Chinese Logic for Global Development [M]. Beijing: China Democracy and Legal Publishing House, 2015.

[9]. Li Xin, Zhang Xin. An Analysis of Regional Integration Development in the Perspective of "One Belt and One Road" [J]. Journal of Xinjiang Normal University: Philosophy and Social Science Edition, 2016(4):109-115.

[10]. Hu Zhiyuan, Ren Wending. Research on the "One Belt and One Road" Development Strategy under Regional Economic Integration [J]. Western Leather, 2017, 39(6): 87-87. 